\title{
Poczq̨tki Oddziału Neurochirurgii Wydziału Lekarskiego Uniwersytetu Warszawskiego i współpraca z Instyłutem Neurologicznym w Montrealu
}

\author{
Jerzy Bidziński
}

Neurologia i Neurochirurgia Polska 2012; 46, 3: 297-299

DOI: 10.5114/ninp.2012.29139

Profesor Kazimierz Orzechowski, kierownik Kliniki Chorób Nerwowych Wydziału Lekarskiego Uniwersytetu Warszawskiego, był wielkim zwolennikiem powstania neurochirurgii jako osobnej specjalności, zajmującej się diagnostyką instrumentalną i operacyjnym leczeniem wybranych chorób układu nerwowego w tamtym okresie (lata 30. ubiegłego wieku) głównie nowotworów mózgu. Uważał, że osobna specjalność zapewni lepsze wyniki leczenia niż dotychczas osiagane po operacjach wykonywanych na ogólnych oddziałach chirurgicznych.

Wśród trudności najmniejszy był problem personalny. Od 1928 r. asystentem kliniki był Jerzy Choróbski, zaawansowany naukowo w neurologii klinicznej i neuropatologii, który bezpośrednio po dyplomie przebywał w Paryżu i tam obserwował operacje neurochirurgiczne. Chciał się poświęcić tej specjalności, znał angielski, niemiecki i francuski, co dawało możliwości szkolenia praktycznie wszędzie.

Wybór miejsca specjalizacji niewątpliwie nastręczał pewne trudności. Ośrodki francuskie poznał Choróbski bezpośrednio po studiach, a innych znaczących ośrodków w Europie nie było. Pozostawały więc ośrodki amerykańskie, w których zresztą nowoczesna neurochirurgia się kształtowała. Wybrano ośrodek neurochirurgiczny przy Uniwersytecie McGill w Montrealu w Kanadzie, gdzie uznany już w kręgach specjalistów Wilder Penfield właśnie tworzył placówkę o charakterze zarówno klinicznym, jak i badawczym, zajmująca się szeroko pojętym zagadnieniem chorób układu nerwowego, ze szczególnym uwzględnieniem neurochirurgii. Przy wsparciu głównego fundatora, Fundacji Rockefellera, oraz licznych innych darczyńców utworzono i otwarto w 1934 r. instytut, trwale związany z osobą profesora Wildera Penfielda - Montreal Neurological Institute (MNI), będący autonomiczną jednostką w ramach Uniwersytetu McGill. Został on zaplanowany i zrealizowany $\mathrm{z}$ wielkim rozmachem. Poza częścią szpitalną miał niezwykle rozbudowane działy i pracownie naukowe, które zresztą ulegały dalszej rozbudowie w miarę upływu lat. Dość powiedzieć, że po kilku latach, poza klinikami neurochirurgii i neurologii, działały już pracownie: radiologiczna, neurofizjologiczna i EEG, neuropatologiczna, neuroanatomiczna, biochemiczna, neuropsychologiczna, a w następnych latach - zespół anestezjologiczny. Audytorium na 120 miejsc służyło do codziennych odpraw porannych i wykładów. Ten wielki i naukowo wybitny ośrodek był miejscem, w którym w kolejnych dziesięcioleciach pobierało naukę i doskonaliło swe umiejętności wielu wybitnych neurochirurgów, kładących podwaliny pod tę specjalność w swoich krajach.

Pozostały do rozwiązania sprawy finansowe, gdyż w żadnym przypadku kosztów wieloletniej specjalizacji Jerzego Choróbskiego nie mógł pokryć szpital czy uczelnia. Pewne znaczenie miał przypadek. Otóż w 1929 r. Madeleine L. Ottman założyła fundację Foundation for Research in Epilepsy i z grantem 10 tys. dolarów przekazała fakultetowi medycznemu Uniwersytetu McGill w Montrealu, zapewne dlatego, że Wilder Penfield, organizujący Instytut Neurologiczny, szczególnie interesował się leczeniem - zwłaszcza operacyjnym - padaczki (od czasu wspólnych prac z Otfridem Foersterem we Wrocławiu). Przy poparciu i rekomendacji profesora Orzechowskiego stypendium związane z tą fundacją otrzymał Jerzy Choróbski, przygotowany pod każdym względem do spełnienia stawianych wymagań. Choróbski spędził więc dwa lata, ucząc się neurochirurgii, ale jednocześnie wraz z Penfieldem wykonał doświadczalną pracę na małpach, dotyczącą przebiegu nerwów rozszerzających naczynia mózgowe [1].

Po zakończeniu okresu stypendium pracował przez rok jako rezydent w Klinice Neurochirurgii Northwestern University Medical School w Chicago. W dokończeniu specjalizacji w neurochirurgii pomogła mu Fun- 
dacja Rockefellera. Jak wynika z dokumentów, za rada profesora Orzechowskiego stypendium Fundacji zostało przeznaczone na dokończenie specjalizacji w neurochirurgii dla Jerzego Choróbskiego. Wrócił więc w 1934 r. do właśnie formalnie wtedy otwartego instytutu w Montrealu i dołączył do grona pierwszych 11 asystentów (Research Fellows and House Staff), wśród których byli m.in. J. Evans i A. Tordkilksen. Po ukończeniu rezydentury w ramach tego stypendium przebywał po kilka tygodni w innych znanych ośrodkach amerykańskich.

Po powrocie do kraju, pod koniec 1935 r. otworzył Oddział Neurochirurgii Kliniki Chorób Nerwowych Uniwersytetu Warszawskiego, który prowadził z pomoca Adama Kunickiego i Ernesta Ferensa. Lata wojenne i bezpośrednie lata powojenne spowodowały całkowite zerwanie więzi z Instytutem Neurologicznym w Montrealu.

Dopiero po przełomie społeczno-politycznym w Polsce, 18 lutego 1957 r., do Polski przyjechała pięcioosobowa delegacja przedstawicieli Fundacji Rockefellera z zadaniem ponownego objęcia Polski pomocą finansową. Delegacji przewodniczył członek Zarządu Głównego Fundacji, dr Warren Weaver, który wyraził zadowolenie, że: „między naszą instytucją a polską nauką wznowione zostaną dawne przyjacielskie stosunki”. W składzie delegacji byli dyrektorzy m.in. Wydziału ds. Szkolnictwa Medycznego i Zdrowia Publicznego oraz przedstawiciel Fundacji na Europe, pp. O.L. Peterson i J. Maier. Przedstawiciele Fundacji przybyli również do swojego byłego stypendysty, profesora Jerzego Choróbskiego, który przedstawił swych kandydatów do stypendiów naukowych.

W wyniku rozmów kwalifikacyjnych stypendium Fundacji Rockefellera w pierwszym okresie otrzymali Lucjan Stępień i Jerzy Bidziński. Dzięki temu odnowiły się kontakty Kliniki Neurochirurgii z Instytutem Neurologicznym w Montrealu.

Lucjan Stępień (późniejszy kierownik Kliniki), przebywał w instytucie w Montrealu na przełomie 1958 i 1959 r. Zgodnie ze swoimi zainteresowaniami, zagadnieniem tzw. świeżej pamięci, wykonał on wraz z innymi pracę doświadczalną na małpach, której efektem były dwie publikacje $[2,3]$.

Jerzy Bidziński (następny kierownik kliniki) studiował w Instytucie w 1958 i 1959 r. i zapoznawał się głównie z zagadnieniem diagnostyki i operacyjnego leczenia padaczki, zwłaszcza skroniowej, oraz problemem znieczulenia w neurochirurgii. Doświadczenia związane z pobytem w Instytucie Neurologicznym w Montrealu były podstawą jego pracy habilitacyjnej.
Następnie twórczo przez wiele lat rozwijał on zagadnienie operacyjnego leczenia padaczki przez poszerzenie diagnostyki oraz techniki operacyjnej w kierowanej przez niego klinice, która stała się najpoważniejszym ośrodkiem, również w skali międzynarodowej, zajmującym się tym zagadnieniem.

W 1959 r. jeden z pierwszych uczniów Wildera Penfielda, profesor Jerzy Choróbski, otrzymał tytuł doktora honoris causa Uniwersytetu McGill w Montrealu. $\mathrm{W}$ ten sposób po wieloletniej przerwie nawiązały się kontakty pomiędzy Kliniką Neurochirurgii w Warszawie i Instytutem Neurologicznym w Montrealu.

W 1960 r. kolejnym stypendystą Fundacji Rockefellera był Stanisław Toczek, jednak po skończeniu stypendium nie powrócił on do pracy w macierzystej klinice i pozostał w USA. Mimo to Fundacja Rockefellera nadal wspierała Klinikę. Następnym stypendystą był Tadeusz Bacia, neurofizjolog kliniczny, który w 1963 r. wyjechał na rok do Instytutu Neurologicznego w Montrealu, do pracowni elektroencefalografii i neurofizjologii klinicznej kierowanej przez Herberta Jaspera. Zapoznał się tam z diagnostyką EEG, szczególnie w padaczce lekoopornej u chorych poddanych następnie leczeniu operacyjnemu oraz z interpretacją zapisu ECoG. Wraz z Hebertem Jasperem zajmował się wywołanymi potencjałami somatosensorycznymi i wzrokowymi [4]. Po powrocie do kraju rozbudował on należącą do Kliniki Pracownię Elektrofizjologii Klinicznej, stał się niekwestionowanym autorytetem w zagadnieniach elektrofizjologicznej lokalizacji ogniska padaczkowego. Był inicjatorem kilku nowych metod diagnostycznych, m.in. zastosowania elektrod implantowanych, a także nieodłącznym i podstawowym współpracownikiem przy operacjach padaczki.

Stypendystą Fundacji Rockefellera był również Jerzy Wisławski. Zgodnie ze swymi zainteresowaniami neuropatologią nowotworów mózgu wyjechał on w 1964 r. na pół roku do Londynu do pracowni neuropatologicznej profesor Dorothy Russel. Po powrocie powiększył należącą do kliniki pracownię neuropatologiczną, sam zaś był szczególnie zainteresowany „złośliwieniem” glejaków oraz histologią guzów przysadki mózgowej, których operacje były jego specjalnością.

Wieloletnia współpraca z ośrodkiem w Montrealu została podkreślona wizytą kilku pracowników instytutu w warszawskiej klinice oraz nadaniem w 1960 r. profesorowi Wilderowi Penfieldowi doktoratu honoris causa Akademii Medycznej w Warszawie.

$\mathrm{Na}$ zakończenie pragnę zwrócić uwagę na pomijane zwykle, a tak bardzo ważne, zagadnienie, jakim jest istot- 
ny wkład Fundacji Rockefellera we wspieranie nauki polskiej, szczególnie w bardzo trudnym okresie powojennym, i w tym miejscu podziękować władzom Fundacji za przyznane pracownikom kliniki stypendia.

\section{Piśmiennictwo}

1. Choróbski J., Penfield W. Cerebral vasodilator nerves and their pathway form the medulla oblongata. Arch Neurol Psychiatry 1932; 28: 1257-1289.

2. Stępień L., Cordeau J.P., Rasmussen Th. The effect of temporal lobe and hippocampal lesions on auditory and visual recent memory in monkeys. Brain 1960; 83: 470-489.

3. Stępień L., Cordeau J.P. Memory in monkeys for compound stimuli. Am J Psychol 1960; 73: 388-395.

4. Bacia T., Jasper H., Reid J. Somatosensory and visual evoked responses in patients with epilepsy. EEG Clin Neurophysiol 1965; 18: 718 . 